\title{
Interactive Effects of Temperature, Nitrogen, and Zooplankton on Growth and Protein and Carbohydrate Content of Cyanobacteria from Western Lake Erie
}

\author{
Deepesh Bista ${ }^{*}$, Scott A. Heckathorn1, Thomas Bridgeman ${ }^{1,2}$, Justin D. Chaffin ${ }^{3}$, \\ Sasmita Mishra ${ }^{1}$ \\ ${ }^{1}$ Department of Environmental Sciences, University of Toledo, Toledo, USA \\ ${ }^{2}$ Lake Erie Center, University of Toledo, Toledo, USA \\ ${ }^{3}$ F.T. Stone Laboratory, The Ohio State University, Columbus, USA \\ Email: ${ }^{\text {deepesh.bista@rockets.utoledo.edu }}$
}

Received 27 June 2014; revised 25 July 2014; accepted 21 August 2014

Copyright @ 2014 by authors and Scientific Research Publishing Inc.

This work is licensed under the Creative Commons Attribution International License (CC BY). http://creativecommons.org/licenses/by/4.0/

(c) (i) Open Access

\section{Abstract}

Harmful algal blooms (HABs) in freshwater ecosystems, especially of cyanobacterial species, are becoming more frequent and expanding geographically, including in Lake Erie in North America. HABs are the result of complex and synergistic environmental factors, though $\mathrm{N}$ or $\mathrm{P}$ eutrophication is a leading cause. With global mean temperatures expected to increase an additional $2^{\circ} \mathrm{C}-5^{\circ} \mathrm{C}$ by 2100 , cyanobacterial blooms are predicted to increase even more, given their typically-high temperature optimum for growth. We investigated how increases in temperature and nitrogen, singly or in combination, affect the growth, food quality, and herbivory of Lake Erie cyanobacteria. Algal community samples collected from Lake Erie, and isolated non- $\mathrm{N}$-fixing (Microcystis aeruginosa) and $\mathrm{N}$-fixing (Anabaena flos-aquae) cyanobacterial species, were cultured at $20^{\circ} \mathrm{C}, 25^{\circ} \mathrm{C}$, or $30^{\circ} \mathrm{C}$, and at 5, 50, 150, or $250 \mu \mathrm{M} \mathrm{N}$, and then analyzed for growth and (for isolates) content of total protein and non-structural carbohydrates (NSC). Temperature and $\mathrm{N}$ both affected algal growth, and there were temperature $\times \mathrm{N}$ interactions, which were sometimes affected by presence/absence of zooplankton. For example, cyanobacteria (but not green algae) growth increased with both temperature and $\mathrm{N}$, especially from $25^{\circ} \mathrm{C}$ to $30^{\circ} \mathrm{C}$, but $\mathrm{N}$ and herbivore presence increased cyanobacterial growth primarily only at $30^{\circ} \mathrm{C}$. In general, temperature and $\mathrm{N}$ had little consistent effect on NSC, but increasing temperature and $\mathrm{N}$ tended to increase protein content in Microcystis and Anabaena (temperature effects mostly at higher $\mathrm{N}$ levels). In Anabaena, increases in $\mathrm{N}$ did not increase growth or protein at $20^{\circ} \mathrm{C}$ or $25^{\circ} \mathrm{C}$, but did increase both at $30^{\circ} \mathrm{C}$, indicating that $\mathrm{N}$ fixation

\footnotetext{
${ }^{*}$ Corresponding author.
} 
is damaged at high temperatures and that high $\mathrm{NO}_{3}$ can overcome this damage. These results indicate that future global warming and continued eutrophication will increase cyanobacterial growth, as well influence algal herbivory and competition between $\mathrm{N}$-fixing and non- $\mathrm{N}$-fixing cyanobacteria.

\title{
Keywords
}

\author{
Cyanobacteria, Great Lakes, Harmful Algal Blooms, Nitrogen, Temperature
}

\section{Introduction}

Harmful algal blooms (HABs) in freshwater ecosystems, especially of cyanobacterial species, have been a major concern worldwide [1] [2]. Cyanobacterial HABs (cyanoHABs) are expanding geographically and now threaten the ecological integrity and sustainability of some of the world's most-important water bodies (e.g., Lake Victoria, Africa; Lake Okeechobee, Florida, USA; Lake Kasumigaura, Japan [3]; Lake Taihu, China [4]; the Baltic Sea in Northern Europe [5]; and the Caspian Sea in West Asia [1]). CyanoHABs cause serious economic losses; e.g., in the United States alone, cyanoHABs result in losses of recreational, drinking, and agricultural water resources that are worth $\$ 2$ billion annually [6]. In addition, cyanoHABs have widespread negative ecological consequences, including decreasing the growth, survivorship, and fecundity of freshwater zooplankton, on which fish communities are dependent (e.g., cyanobacteria can affect their herbivores by clogging their feeding apparatus (colonial algae), by being of low nutritional value, or by producing toxins) [7]. Most cyanoHABs may have endotoxins (internal secondary metabolites) which poison susceptible taxa that ingest them, or they may excrete toxins or inhibitors which affect taxa that may or may not ingest them [8]. Herbivory effects of cyanoHABs may have important effects on zooplankton population dynamics and community structure [9]. Such effects on zooplankton may then secondarily influence organisms at higher trophic levels, creating complex and wide-ranging changes in the ecosystem [10].

As with HABs in general, cyanoHABs are the result of complex and synergistic environmental factors, rather than a single dominant variable [1] [11] [12], however, the relative availability of mineral nutrient resources in the aquatic environment plays a major role in structuring phytoplankton communities [13]. Eutrophic and poorly-flushed waters are typically associated with cyanobacterial blooms [14]-[16]. Nutrient loading rates into many freshwater ecosystems have dramatically increased, due to human population, agriculture, and industrial activities [17]-[19]. As surface waters become enriched in $\mathrm{N}$ or (especially) $\mathrm{P}$, cyanobacteria often dominant the phytoplankton community [1] [20]-[22]. However, not all cyanobacteria are able to utilize (fix) atmospheric $\mathrm{N}_{2}$, and so availability of dissolved inorganic $\mathrm{N}$ (e.g., $\mathrm{NO}_{3}, \mathrm{NH}_{4}$ ) may be equally important in the occurrence of non-N-fixing cyanobacteria blooms, such as Microcystis species [23]-[25]. Laboratory studies have indicated that increases in nitrogen $(\mathrm{N})$ result in increases in the growth and toxicity of Microcystis species [23] [26] [27], and toxic strains of Microcystis can outgrow non-toxic strains at high nitrogen levels [28]. Increasing $\mathrm{N}$ should also affect the food quality of algae by increasing protein content [29] [30].

In addition to eutrophication, human activities are causing an increase in the mean surface temperature of the Earth [31], with projected increases of $c a .2^{\circ} \mathrm{C}-5^{\circ} \mathrm{C}$ by 2100, and this increase in temperature will likely increase HABs in general, and cyanoHABs in particular [1]. For example, as temperature increases, in general, the algal group with the highest growth rate changes from diatoms to green algae to cyanobacteria in the lakes [32]. Often in temperate freshwater eutrophic systems, cyanobacteria dominate phytoplankton assemblages during the warmest months [1] [16] [22] [25] [33]. Harmful cyanobacteria such as Microcystis have been found to have an optimal temperature for growth and photosynthesis at, or above, $25^{\circ} \mathrm{C}$ [1] [11] [34]-[36]. Furthermore, above $25^{\circ} \mathrm{C}$, the cellular toxin content of multiple genera of cyanobacteria increases with increasing temperature [14] [23] [37]. Increasing temperature also can affect the food quality of algae, such as by changing protein or carbohydrate content [30] [38].

As with most ecosystems world-wide, Lake Erie (one of the Laurentian Great Lakes of North America) is experiencing an increase in $\mathrm{N}$ concentrations caused by human activities, and consistent with global warming predictions, the lake has also experienced recent increases in temperature and cyanoHABs [25]. Since the late 
1990s, western Lake Erie has been plagued with cyanobacterial blooms dominated by the non-N-fixing cyanobacterium Microcystis aeruginosa [39] [40]. Although phosphorus may be the main driver of HABs in Lake Erie, nitrogen is important as a limiting nutrient in late summer when HABs reach their peak [22] [25]. Importantly, the interactive effects of increases in both temperature and inorganic $N$ on cyanoHABs in the Great Lakes is not well understood, including effects on the dominant non-N-fixing $v s$. N-fixing cyanoHAB species in the system, and effects on algal food quality.

The overarching objective of this research was to investigate how global warming and nitrogen-enrichment in combination will influence phytoplankton assemblages in Western Lake Erie during the late summer, when inorganic $\mathrm{N}$ concentrations in the lake are decreasing and both $\mathrm{N}$-fixing and non- $\mathrm{N}$-fixing cyanobacterial species are competing. In addition, we investigated the effects on $\mathrm{N}$ and temperature on algal food quality (concentration of non-structural carbohydrate and protein) and susceptibility to herbivory, to gain insight into the combined effects of temperature and $\mathrm{N}$ on algae-herbivore interactions. We hypothesized that increases of both temperature and nitrogen will favor cyanobacteria over green algae and diatoms, that high $\mathrm{N}$ would favor non- $\mathrm{N}$-fixing cyanobacteria, and that high $\mathrm{N}$ would increase food quality and hence herbivory of cyanobacteria, but high temperature would do the opposite.

\section{Methods and Procedures}

\subsection{Lake Algae Sampling and Lab Species Selection}

Experiments were conducted with either: 1) natural algal community samples obtained from Lake Erie during late summer and early fall (2011); or 2) isolates of the cyanobacterial species, Microcystis aeruginosa (K.) and Anabaena flos-aquae (B.), obtained from the University of Texas Culture Collection with LB 2385 and LB 2557 as isolate number, respectively. In most summers, western Lake Erie experiences a bloom of non-N-fixing Microcystis spp. (primarily M. aeruginosa) during July and August, when lake dissolved inorganic $\mathrm{N}$ (mostly $\mathrm{NO}_{3}$ ) concentrations are high (e.g., $\geq 200 \mu \mathrm{M}$ ), and then a second bloom of a $\mathrm{N}$-fixing species (Anabaena spp.) under low $\mathrm{N}$ conditions (e.g., $<10 \mu \mathrm{M}$ or even zero) occurs in the late summer or early fall [22].

Lake samples were collected from three sites in the western part of Lake Erie, near Toledo, $\mathrm{OH}$, and then mixed together in a large tank to ensure that algal diversity in experiments reflects that of the lake in general [collection sites: a shallow (2 m) sediment-laden site adjacent to and heavily influenced by the Maumee River; a medium-depth $(6 \mathrm{~m})$ site just northeast of Maumee Bay on the outskirts of the river sediment plume; and, a deeper $(8.5 \mathrm{~m})$ open-water low-sediment site influenced by the Detroit River. Lake algal samples were collected during 2011 on four dates (26 Aug., 13 Sept., 28 Sept., and 12 Oct.). Sampling dates included late summer dates when non-N-fixing Microcystis spp. were dominant, and in the fall when Microcystis was declining and other $\mathrm{N}$-fixing cyanoHAB species became more common. $\mathrm{NO}_{3}$ levels in lake water were $<28 \mu \mathrm{M}$ on all dates, and water temperatures ranged from $20.8^{\circ} \mathrm{C}-24.4^{\circ} \mathrm{C}$.

\subsection{Culture Methods and Treatments}

After mixing, lake samples were divided into two different groups: 1) unaltered lake water that was used directly in experiments and that contained native zooplankton (including herbivores), as well as algae; and 2) lake water that was first aerated with either $\mathrm{N}_{2}$ or air for $24 \mathrm{~h}$ prior to use in experiments. $\mathrm{N}_{2}$ aeration was used to kill algal herbivores by asphyxiation, and comparison of algal growth with or without $\mathrm{N}_{2}$ aeration allowed for the determination of interactive effects of $\mathrm{N}$, temperature, and herbivory on algal growth; air bubbling was used to determine the effect of bubbling alone on algae.

Lake samples ( $1 \mathrm{~L}$ replicates) were grown in $2 \mathrm{~L}$ clear-plastic bottles covered with a sterile plug that permitted gas exchange. Samples were incubated under one of four concentrations of $\mathrm{N}(5,50,150$ or $250 \mu \mathrm{M}$ of added $\mathrm{NO}_{3}$ ) and one of three levels of temperature $\left(20^{\circ} \mathrm{C}, 25^{\circ} \mathrm{C}\right.$ or $30^{\circ} \mathrm{C}$ ) (4 replicates per treatment combination). Nitrate levels in western Lake Erie typically range from ca. $250 \mu \mathrm{M}$ during the spring runoff and early summer, to as low as $1 \mu \mathrm{M}$ in the fall, and the algal community starts to shift from non- $\mathrm{N}$-fixers to $\mathrm{N}$-fixers between 50 and $150 \mu \mathrm{M} \mathrm{N}$ [25]. The three temperature treatments represent three different scenarios: $20^{\circ} \mathrm{C}=$ typical contemporary early-summer water temperature; $25^{\circ} \mathrm{C}=$ typical contemporary late-summer water temperature; and $30^{\circ} \mathrm{C}$ represents maximum summer water temperature under a future global-warming scenario of $+5^{\circ} \mathrm{C}$. All sam- 
ples were grown in controlled-environment chambers for 11 days, under a 14-h photoperiod of $80 \mu \cdot \mathrm{mol} \cdot \mathrm{m}^{-2} \cdot \mathrm{s}^{-1}$ PAR.

Isolated strains of $M$. aeruginosa and A. flos-aquae were first cultured in autoclaved $1 \mathrm{~L}$ jars containing 250 $\mathrm{ml}$ of complete WC nutrient medium [41] [1 $\mathrm{mM} \mathrm{NaNO}_{3}, 250 \mu \mathrm{M} \mathrm{CaCl}_{2}, 150 \mu \mathrm{M} \mathrm{MgSO}_{4}, 50 \mu \mathrm{M} \mathrm{K}_{2} \mathrm{HPO}_{4}$, $11.7 \mu \mathrm{M}$ Fe-EDTA, $0.9 \mu \mathrm{M} \mathrm{MnCl}_{2}, 0.08 \mu \mathrm{M} \mathrm{ZnSO}_{4}, 0.05 \mu \mathrm{M} \mathrm{CoCl}_{2}, 0.04 \mu \mathrm{M} \mathrm{CuSO}, 10 \mu \mathrm{M} \mathrm{H}_{3} \mathrm{BO}_{3}$, and $0.0037 \mu \mathrm{M}\left(\mathrm{NH}_{4}\right)_{6} \mathrm{Mo}_{7} \mathrm{O}_{24}$; plus TES buffer $\left.(115 \mathrm{gm} / \mathrm{L})\right]$, under the same the growth chamber settings as for lake samples, but at $27^{\circ} \mathrm{C}$. Jars were capped with filter paper to allow gas exchange, but prevent contamination by other algae. After $7 \mathrm{~d}$ of growth, cultures were examined under a light microscope to ensure absence of algal contamination, and these stocks were used for the experiment. Replicates of a single stock of each species were grown for $11 \mathrm{~d}$ at the $\mathrm{N}$ and temperature levels as in the lake-algae experiment.

In preliminary experiments, we analyzed the utility of $\mathrm{N}_{2}$ bubbling in killing zooplankton by asphyxiation. In an initial experiment, a non-sterile culture of an unidentified green-algal Chlorella species from Lake Erie, contaminated with various rotifers, was aerated for $20 \mathrm{~h}$ with $\mathrm{N}_{2}$ and then incubated in low light at room temperature for $4 \mathrm{~d}$. In a second confirmatory experiment, lake water containing a mix of algal species and zooplankton was bubbled with either air or $\mathrm{N}_{2}$ (or nothing) for $7 \mathrm{~d}$, and zooplankton density of these samples ( $\mathrm{n}=4$ per treatment) was determined microscopically on day 0,1 and 7 . $\mathrm{N}_{2}$ bubbling was effective in killing algal herbivores in both experiments [42].

\subsection{Pigment Content}

Algae were harvested on GF/C filters, and then immediately stored at $-80^{\circ} \mathrm{C}$. Samples were analyzed for content of chlorophyll $a$ (as a measure of total algal growth rate), chlorophyll $b$ (green algal growth rate), chlorophyll $c$ (diatom growth rate), and phycocyanins (cyanobacteria). Chlorophyll content was determined spectrophotometrically, after extraction with DMSO and dark incubation at $65^{\circ} \mathrm{C}$, using formulas and absorbance wavelengths for chl $a \& b$ [43] and for chl $c$ [44]. Following the procedures of Chaffin [45] and equations of Furuki [46] and Sampath and Neefus [47], phycocyanin content was determined after sonication (to break cells) for 15 min at $4^{\circ} \mathrm{C}$ in $0.1 \mathrm{M}$ phosphate buffer (pH 6.8) (Bransonic \#1510). Samples were then incubated for $1 \mathrm{~h}$ at $4^{\circ} \mathrm{C}$, and centrifuged for $10 \mathrm{~min}$ at $3800 \mathrm{~g}$. Phycocyanin concentration of samples was determined by fluorescence (10-AU fluorometer with P/N 10 - 305 filters, Turner Design). Pigment contents (excluding phycocyanin) are expressed as final minus initial concentrations divided by initial concentrations divided by 11 days of growth; hence, results are expressed as relative growth rates.

\subsection{Non-Structural Carbohydrate (CHO) and Protein}

Total non-structural carbohydrate in Microcystis and Anabaena were extracted by grinding the harvested GF/C filter with algae to a powder in liquid nitrogen using a mortar and pestle. Then $1 \mathrm{~mL}$ of $0.1 \mathrm{~N} \mathrm{NaOH}$ was added and kept at $50^{\circ} \mathrm{C}$ for 30 minutes followed by $1 \mathrm{ml}$ of $0.1 \mathrm{~N} \mathrm{HCl}$. Then $1 \mathrm{ml}$ of enzyme solution containing 3000 Units/mL of $\alpha$-amylase +15 Units/mL of amyloglucosidase in $0.05 \mathrm{M} \mathrm{Na}$-acetate buffer (pH 5.0) was added and kept for 24 hours at $50^{\circ} \mathrm{C}$ with occasional vortexing. After enzyme incubation, solution was filtered through a $0.22 \mu \mathrm{M}$ filter to remove digesting enzymes (e.g., using a Millipore microfuge filter unit). Total non-CHO content was estimated by using the phenol-sulfuric acid method of Dubois [48], with minor modification and absorbance was read at $490 \mathrm{~nm}$, using glucose to generate a standard curve.

Increase in total protein content (TPC) is an indicator of potential growth rate increase [49]-[51]. Microcystis and Anabaena proteins were extracted by grinding the harvested GF/C filter to a powder in liquid nitrogen using mortar and pestle, then transferred to a protein extraction buffer containing 1\% sodium dodecyl sulfate (SDS) detergent, $0.1 \mathrm{M}$ Tris buffer $(\mathrm{pH}=8.0), 10 \%$ glycerol or $10 \%$ sucrose, protease inhibitors ( $1 \mathrm{mM}$ phenylmethylsulfonyl fluoride (PMSF), $1 \mathrm{mM}$ EDTA, $1 \mathrm{mM}$ benzamidine, and $10 \mu \mathrm{M}$ leupeptin), a phenolic inhibitor (0.5\% polyvinylpolypyrrolidone (PVPP)), and reductants (10 mM dithiothreitol (DTT) and $0.1 \mathrm{M}$ ascorbic acid) [52]. Samples were then centrifuged at $15,000 \mathrm{~g}$ for $10 \mathrm{~min}$ at $4^{\circ} \mathrm{C}$. Supernatant containing soluble proteins was collected and total protein concentration of each sample was determined in triplicate by the Coomassie-dye-binding method of Ghosh [53], using bovine serum albumin (BSA) as a standard and normalized to gram dry weight. The colorimetric density of protein in sample spots on filter-paper discs was determined using a desktop scanner and densitometry analysis, using imaging software (Scion, National Institutes of Health, Bethesda, MD). 


\subsection{Statistical Analysis}

Results were first analyzed using Analysis of Variance (ANOVA). For field samples, 4-way ANOVA was initially used to examine main-factor effects of temperature, N, sampling date, and \pm herbivores (excluding 26 Aug., which was analyzed separately using 2-way ANOVA). Then 2-way ANOVA (with temperature and N as main factors), followed by Tukey's HSD multiple-comparison test, was conducted within each sampling date and herbivore combination, to better resolve interactive effects of temperature and $\mathrm{N}$ on algal growth. For results from Microcystis and Anabaena isolates, 2-way ANOVA (temperature $\times \mathrm{N}$ ) within each species was conducted, followed by Tukey's test.

\section{Results}

\subsection{Experiment 1-Lake Algae Samples}

In 2011, when water samples were collected from western Lake Erie and used in the laboratory incubation experiment, natural algal communities were typically diverse and the relative abundance of major algal taxa varied with sampling date (Figure 1). On 25 Aug., the algal community was dominated by cyanobacteria (especially $M$. aeruginosa, based on microscopic examination), but on the other sampling dates, diatoms (especially Fragilaria and Aulacoseira spp.) and cryptophytes were abundant too; green algae were only abundant on 13 Sept.

In an initial trial laboratory incubation of lake water samples collected on 26 Aug., both $\mathrm{N}$ and temperature had significant effects $(\mathrm{P}<0.015)$ on cyanobacterial growth (measured as chl $a$ ), and there were marginally-significant interactive effects of $\mathrm{N}$ and temperature $(\mathrm{P}=0.0765) ; \mathrm{N}$ and temperature effects on green algae (chl $b$ ) and diatoms (chl $c$ ) were not significant. In general, algal growth tended to increase with increasing temperature and $\mathrm{N}$, with maximum growth for all algal types at $30^{\circ} \mathrm{C}$ and $250 \mu \mathrm{M} \mathrm{N}$, and $\mathrm{N}$ saturation occurring at lower $\mathrm{N}$ levels at $20^{\circ} \mathrm{C}$ and $25^{\circ} \mathrm{C}$ (Figure 2).

On subsequent sampling dates (13 Sept., 28 Sept., 12 Oct.), lake water samples used in laboratory incubations were either used "as is" (i.e., +zooplankton, including herbivores) or were first bubbled with $\mathrm{N}_{2}$ to kill herbivores. For the total algal community, measured as $\operatorname{chl} a$, there were statistically-significant effects of $\mathrm{N}$, temperature, herbivores, and sampling date on algal growth, and many instances of significant interactive effects $(\mathrm{P}<$ 0.05) of these factors on algae (Figure 3). For example, growth was greater at $30 \mathrm{vs.} 25^{\circ} \mathrm{C}$ and $20^{\circ} \mathrm{C}$ (for which

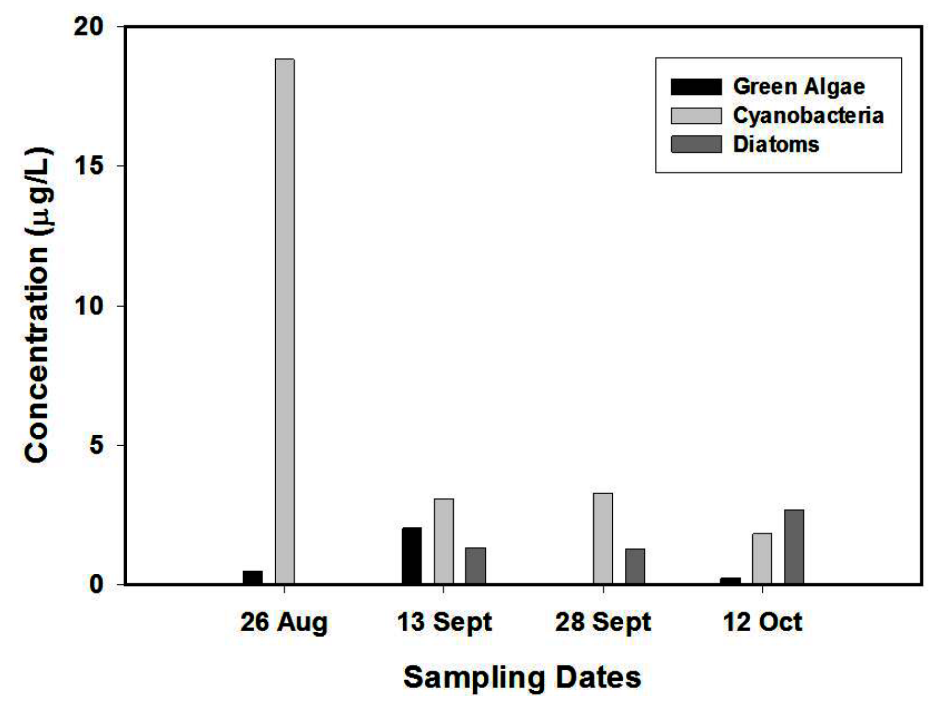

Figure 1. Composition of the 2011 algal community in water samples from Lake Erie used in experiments. Concentrations of the major taxa are expressed in levels of taxa-specific photosynthetic pigments (chl $b$ for green algae, phycocyanins for cyanobacteria, chl $c$ for diatoms, determined by fluorometry (Fluoroprobe, Series 3, bbe moldaenke, Germany). Samples were integrated composites of 3 different sampling sites. 


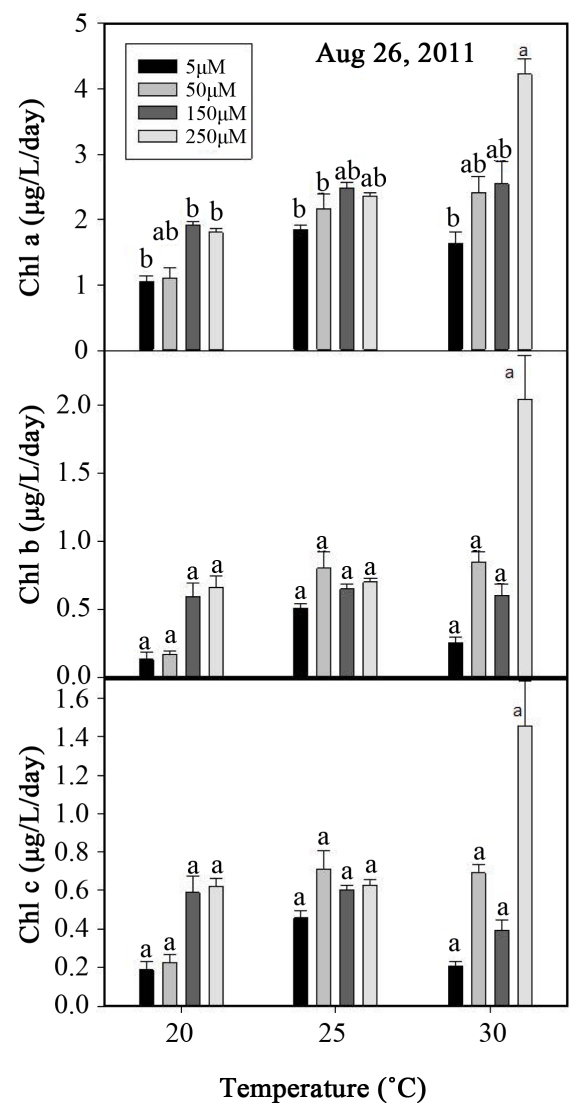

Figure 2. Effect of temperature and $\mathrm{N}$ on the growth of algae collected from western Lake Erie on 26 Aug. 2011. Growth rate of the total algal community (measured as chl $a$ ) vs. green algae (measured as chl $b$ ) and diatoms (measured as chl $c$ ) was determined after incubation for $11 \mathrm{~d}$ at $20^{\circ} \mathrm{C}, 25^{\circ} \mathrm{C}$ or $30^{\circ} \mathrm{C}$ and $5,50,150$ or $250 \mu \mathrm{M}$ added $\mathrm{N}\left(\mathrm{NO}_{3}\right)$. Results are means $+1 \mathrm{SE}, \mathrm{n}=4$. Letters represent groups of significant difference based on Tukey test $(\alpha=0.05)$.

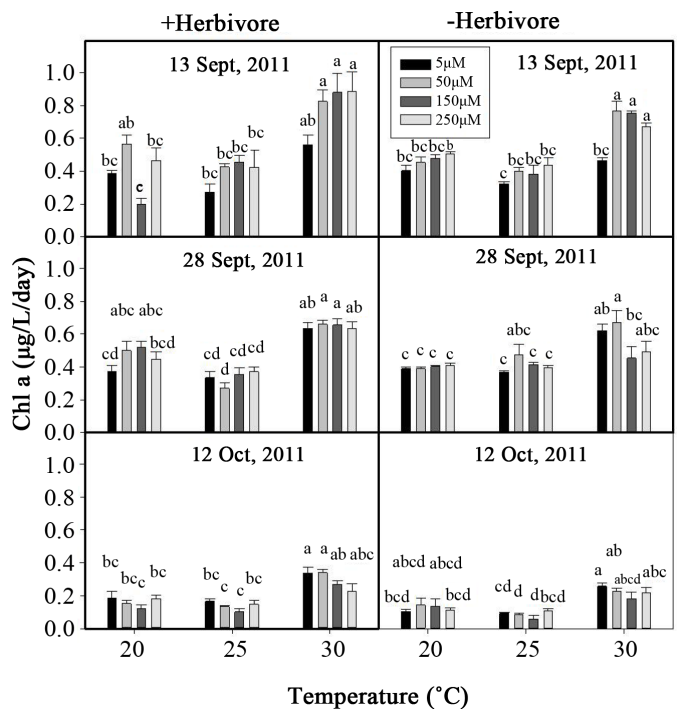

Figure 3. Effects of temperature, N, and herbivory on the growth of algae collected from western Lake Erie on 13 Sept., 28 Sept., and 12 Oct. (2011). Growth of the total algal community rate was measured as chl $a$ after incubation for $11 \mathrm{~d}$ at $20^{\circ} \mathrm{C}$, $25^{\circ} \mathrm{C}$ or $30^{\circ} \mathrm{C}$ and $5,50,150$ or $250 \mu \mathrm{M}$ added $\mathrm{N}\left(\mathrm{NO}_{3}\right)$. Replicate samples were aerated for 24 h with $\mathrm{N}_{2}$ prior to $\mathrm{N}$ and temperature treatments to kill herbivores. Results are means $+1 \mathrm{SE}, \mathrm{n}=4$. Letters represent groups of significant difference based on Tukey test $(\alpha=0.05)$. 
growth was similar; all dates), but $\mathrm{N}$ affected growth only at $30^{\circ} \mathrm{C}$, and the effect of $\mathrm{N}$ depended on date (e.g., increasing growth with $\mathrm{N}$ seen only on $13 \mathrm{Sept}$.). Removal of herbivores tended to increase algal growth early in the season, but had little effect later in Oct., and herbivores affected the response to $\mathrm{N}$ on 28 Sept. Lastly, growth was greater early in the season, compared to 12 Oct.

For green algae, measured as chl $b$, there were statistically-significant effects of herbivores and sampling date on algal growth $(\mathrm{P}<0.001)$, but the effect of temperature was only marginally significant $(\mathrm{P}=0.1397)$, whereas nitrogen has no significant effect and there were only two instances of significant interactive effects $(\mathrm{P}<0.05)$ of these factors on algae (temp $\times$ date, herb $\times$ date) (Figure 4). For example, temperature had little effect on green algal growth early in the season, but growth decreased at high temperature late in the season, and the absence of herbivores resulted in a positive response to temperature on 28 Sept., but resulted in a negative response on 12 Oct.

For diatoms, measured as $\operatorname{chl} c$, there were statistically-significant effects of $\mathrm{N}$, date, and herbivores on algal growth ( $P<0.031$ ), but the effect of temperature was only marginally significant $(P=0.1973)$, and there was only one instance of significant interactive effects $(\mathrm{P}<0.05)$ of these factors on algae (herb $\times$ date) (Figure 5). For example, temperature had little effect on diatom growth, except for a trend of decreasing growth with increasing temperature on 12 Oct. (+,--herbivores) and a trend of increasing growth with temperature on 28 Sept. (-herbivores only). Effects of increasing $\mathrm{N}$ were mostly evident only at $30^{\circ} \mathrm{C}$ (excluding 28 Sept., -herbivores), where $\mathrm{N}$ tended to increase growth and $\mathrm{N}$ benefits tended to saturate at $50 \mu \mathrm{M} \mathrm{N}$.

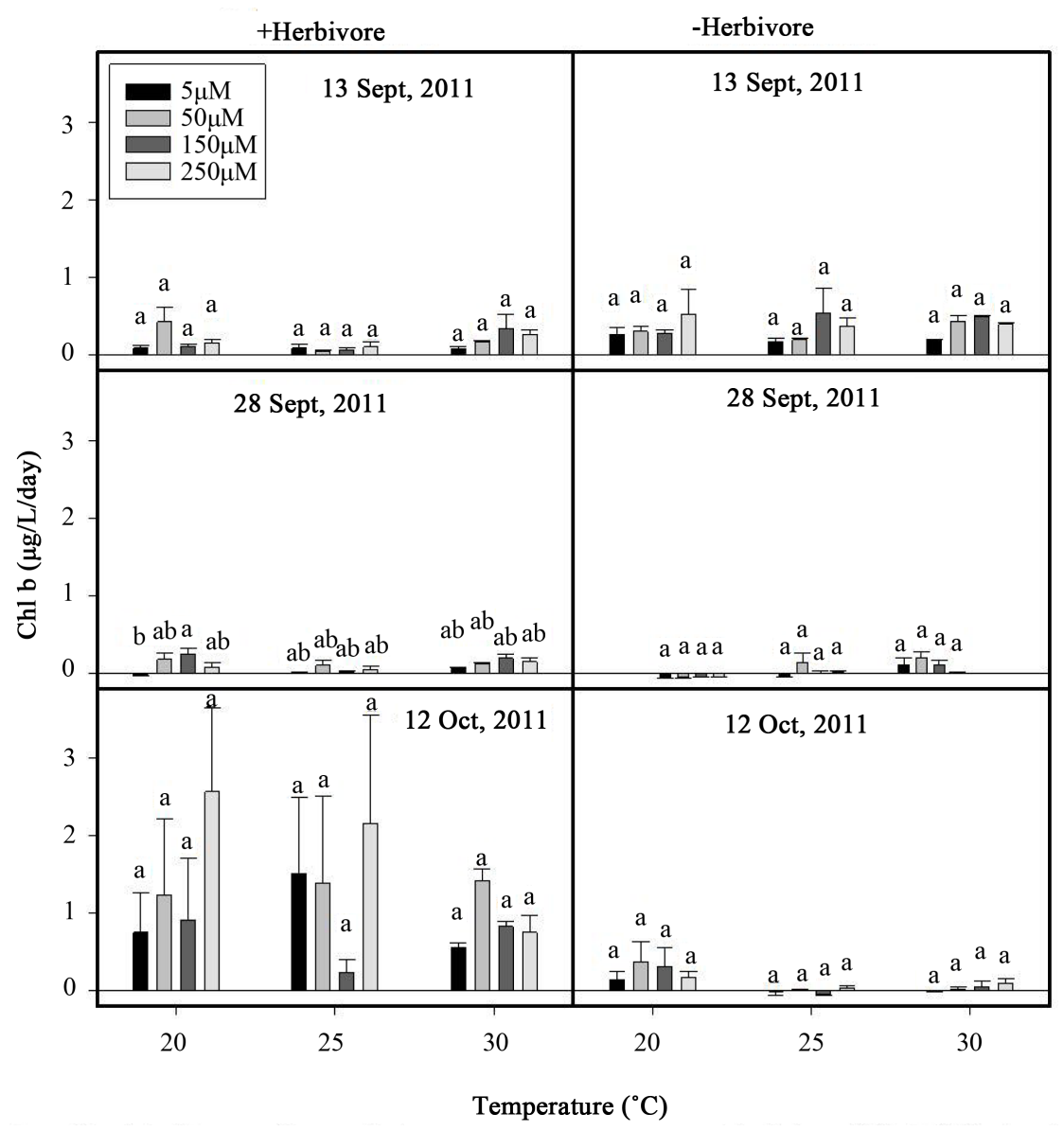

Figure 4. Effects of temperature, N, and herbivory on the growth of algae collected from western Lake Erie on 13 Sept., 28 Sept., and 12 Oct. (2011). Growth of the green algal community rate was measured as chl $b$ after for $11 \mathrm{~d}$ at $20^{\circ} \mathrm{C}, 25^{\circ} \mathrm{C}$ or $30^{\circ} \mathrm{C}$ and 5 , 50,150 or $250 \mu \mathrm{M}$ added $\mathrm{N}\left(\mathrm{NO}_{3}\right)$. Replicate samples were aerated for $24 \mathrm{~h}$ with $\mathrm{N}_{2}$ prior to $\mathrm{N}$ and temperature treatments to kill herbivores. Results are means $+1 \mathrm{SE}, \mathrm{n}=4$. Letters represent groups of significant difference based on Tukey test $(\alpha=0.05)$. 


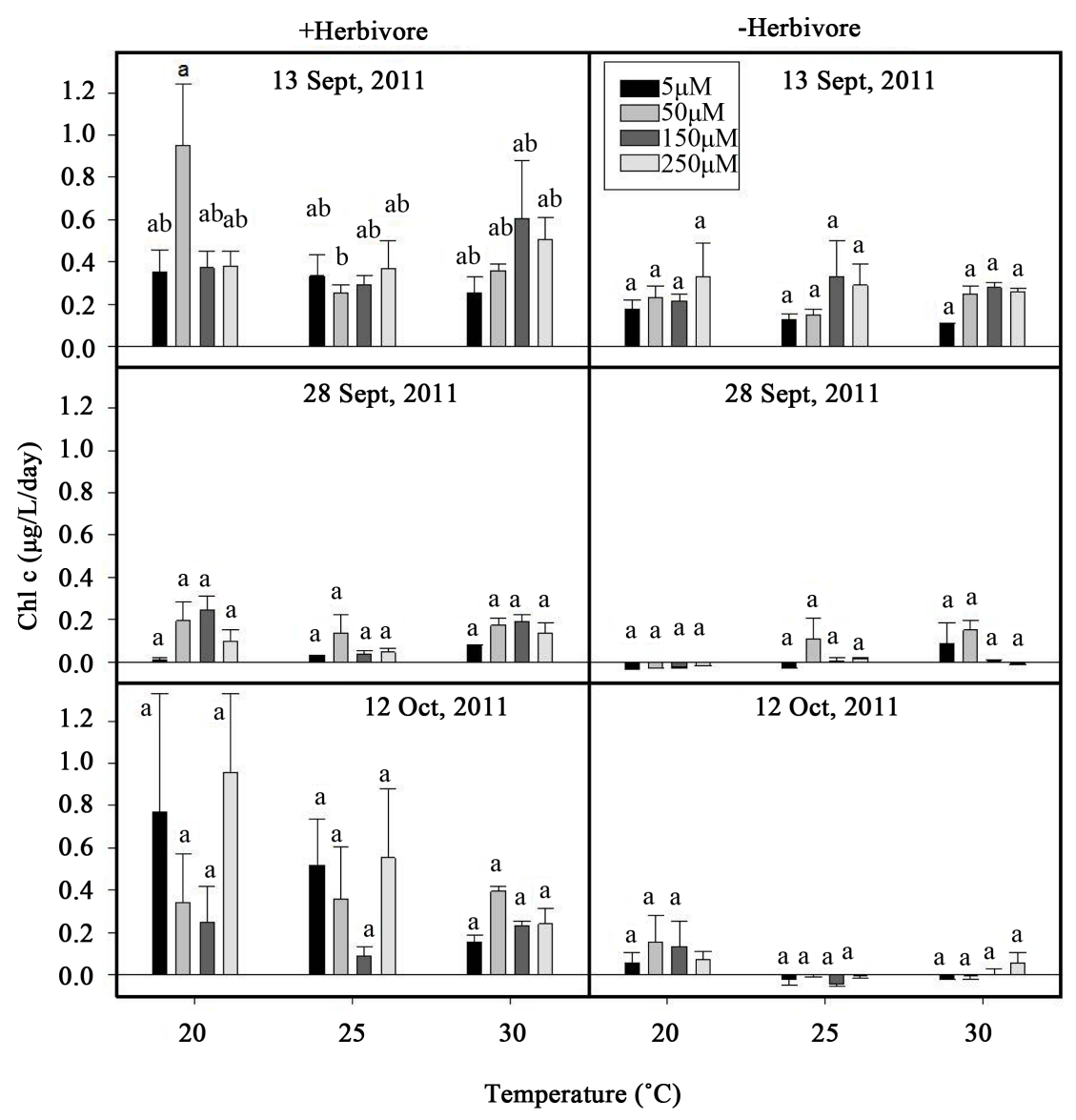

Figure 5. Effects of temperature, $\mathrm{N}$, and herbivory on the growth of algae collected from western Lake Erie on 13 Sept., 28 Sept., and 12 Oct. (2011). Growth of the diatom algal community rate was measured as chl $c$ after incubation for $11 \mathrm{~d}$ at $20^{\circ} \mathrm{C}, 25^{\circ} \mathrm{C}$ or $30^{\circ} \mathrm{C}$ and 5, 50, 150 or $250 \mu \mathrm{M}$ added $\mathrm{N}\left(\mathrm{NO}_{3}\right)$. Replicate samples were aerated for $24 \mathrm{~h}$ with $\mathrm{N}_{2}$ prior to $\mathrm{N}$ and temperature treatments to kill herbivores. Results are means +1 $\mathrm{SE}, \mathrm{n}=4$. Letters represent groups of significant difference based on Tukey test $(\alpha=0.05)$.

For cyanobacteria, measured as phycocyanins, there were statistically-significant effects of N, temperature, herbivores, and sampling date on algal growth $(\mathrm{P}<0.0001)$, and all of the interactive effects of these main factors were significant $(\mathrm{P}<0.05)$, excluding for two instances (temperature $\times \mathrm{N} \times$ herbivore, temperature $\times \mathrm{N} \times$ herbivore $\times$ date) (Figure 6). In general, growth was greater at 30 vs. $25^{\circ} \mathrm{C}$ and $20^{\circ} \mathrm{C}$ (which did not differ), excluding 28 Sept. when herbivores were absent. Growth typically increased with $\mathrm{N}$ early in the season, but not on 12 Oct., and the $\mathrm{N}$ response tended to saturate by 50 - $150 \mu \mathrm{M} N$ (except for 28 Sept., -herbivores). The presence of herbivores tended to increase cyanobacterial growth, suggesting that herbivores consumed competing algae from other taxa, and the removal of competitors made additional resources available to cyanobacteria, thereby increasing their growth. Lastly, cyanobacterial growth was greater early in the season (especially 28 Sept.), and decreased later in the season.

\subsection{Experiment 2-Isolated Cyanobacterial Species}

Growth of pure cultures of non-N-fixing Microcystis and N-fixing Anabaena both increased with temperature $(\mathrm{P}<$ $0.0001)$, and as expected, Microcystis growth increased with $\mathrm{N}(\mathrm{P}<0.0001)$, saturating by $150 \mu \mathrm{M} \mathrm{N}$ at all temperatures (Figure 7). Interestingly, growth of Anabaena did not increase with $\mathrm{N}$ at $20^{\circ} \mathrm{C}$ and $25^{\circ} \mathrm{C}$, but did increase with $\mathrm{N}$ at $30^{\circ} \mathrm{C}$, indicating a decrease in $\mathrm{N}$ acquisition by $\mathrm{N}$-fixation and increased acquisition of $\mathrm{N}$ as $\mathrm{NO}_{3}$, and suggesting that $\mathrm{N}$-fixation may be damaged at $30^{\circ} \mathrm{C}$.

The concentration of protein in Microcystis and Anabaena was affected by temperature and $\mathrm{N}$, and there were 


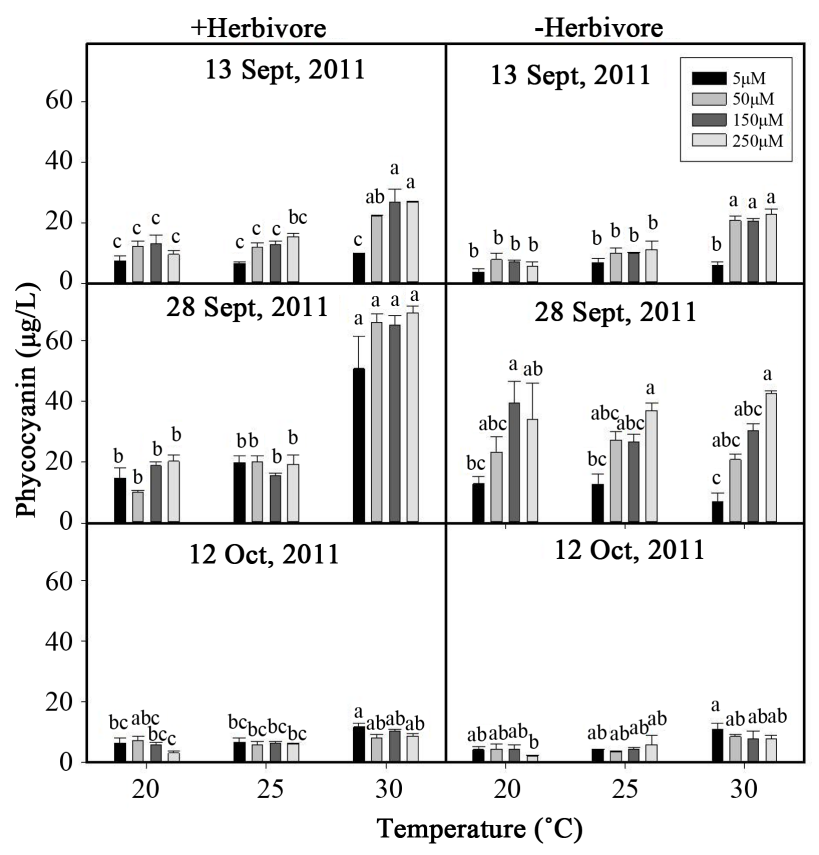

Figure 6. Effects of temperature, N, and herbivory on the growth of algae collected from western Lake Erie on 13 Sept., 28 Sept., and 12 Oct. (2011). Growth of the cyanobacterial algal community was measured as phycocyanin (final minus initial pigment concentration) after incubation for $11 \mathrm{~d}$ at $20^{\circ} \mathrm{C}, 25^{\circ} \mathrm{C}$ or $30^{\circ} \mathrm{C}$ and 5, 50, 150 or $250 \mu \mathrm{M}$ added $\mathrm{N}\left(\mathrm{NO}_{3}\right)$. Replicate samples were aerated for $24 \mathrm{~h}$ with $\mathrm{N}_{2}$ prior to $\mathrm{N}$ and temperature treatments to kill herbivores. Results are means $+1 \mathrm{SE}$, $\mathrm{n}=$ 4. Letters represent groups of significant difference based on Tukey test $(\alpha=0.05)$.

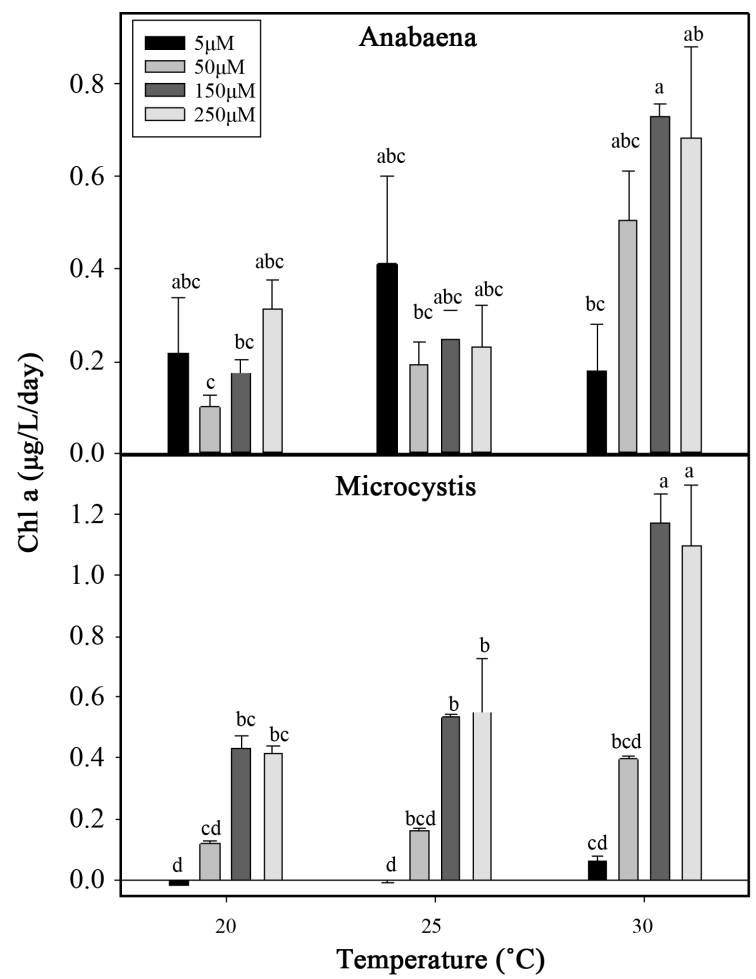

Figure 7. Effect of temperature and $\mathrm{N}$ on the growth of isolated non-N-fixing (M. aeruginosa) and N-fixing (A. flos-aquae) cyanobacterial species that are dominant in western Lake Erie. Growth was measured as chl $a$ after incubation for $11 \mathrm{~d}$ at $20^{\circ} \mathrm{C}, 25^{\circ} \mathrm{C}$ or $30^{\circ} \mathrm{C}$ and $5,50,150$ or $250 \mu \mathrm{M}$ added $\mathrm{N}\left(\mathrm{NO}_{3}\right)$. Results are means $+1 \mathrm{SE}, \mathrm{n}=4$. Letters represent groups of significant difference based on Tukey test $(\alpha=0.05)$. 
significant $\mathrm{N} \times$ species and temperature $\times \mathrm{N}$ interactions on protein concentration (Figure 8). For example, protein concentration was strongly increased by increases in $\mathrm{N}$ in Microcystis, but there was only a non-significant trend for increases in protein with increasing $\mathrm{N}$ in Ananaena at $30^{\circ} \mathrm{C}$ only. Similarly, protein increased with increasing temperature in Microcystis, though only at higher $\mathrm{N}$ levels, and the effects of temperature were less pronounced for Anabaena. In contrast to protein, temperature and $\mathrm{N}$ had little significant effect on NSC concentration (excluding a decrease with $\mathrm{N}$ at $25^{\circ} \mathrm{C}$ in Anabaena).

\section{Discussion}

The overarching objective of this research was to investigate how global warming and $\mathrm{N}$ eutrophication, in combination will influence the growth, species composition, and herbivory of cyanobacterial HABs in a model temperate freshwater system, western Lake Erie. In the present study, as expected, $\mathrm{N}$ and temperature both affected the growth of cyanobacteria and other major algal taxa, there were interactive effects of $\mathrm{N}$ and temperature, and the effects of $\mathrm{N}$ and temperature were influenced by the presence/absence of herbivores, sampling date, and whether cyanobacteria were $\mathrm{N}$-fixers or not. In general, increases in $\mathrm{N}$ or temperature favored growth of cyanobacterial over green algae and diatoms, especially when both $\mathrm{N}$ and temperature were increased and herbivores were present, and, surprisingly, both $\mathrm{N}$-fixing and non-N-fixing cyanobacterial species responded strongly to $\mathrm{N}$ at high temperatures. In terms of food quality, in general, temperature and $\mathrm{N}$ had little consistent effect on NSC, but increasing temperature and N tended to increase protein content in Microcystis (especially) and Anabaena (temperature effects were mostly at higher $\mathrm{N}$ levels).

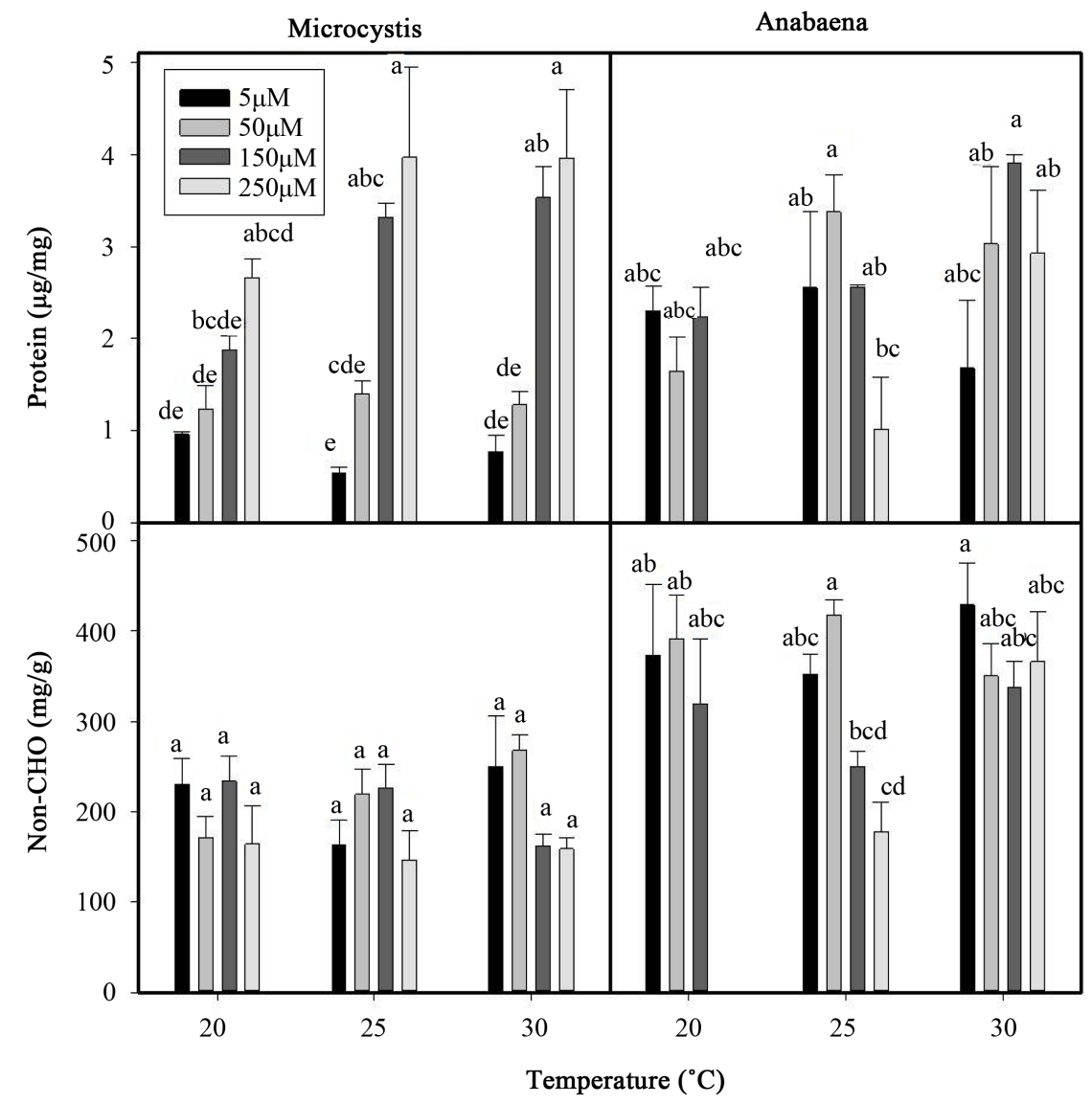

Figure 8. Effects of temperature and $\mathrm{N}$ on protein and non-structural carbohydrate (Non-CHO) content of isolated non-N-fixing ( $M$. aeruginosa) and $\mathrm{N}$-fixing ( $A$. flos-aquae) cyanobacterial species that are dominant in western Lake Erie. Protein and Non-CHO per dry weight was measured after incubation for $11 \mathrm{~d}$ at $20^{\circ} \mathrm{C}, 25^{\circ} \mathrm{C}$ or $30^{\circ} \mathrm{C}$ and $5,50,150$ or $250 \mu \mathrm{M}$ added $\mathrm{N}\left(\mathrm{NO}_{3}\right)$. Results are means $+1 \mathrm{SE}, \mathrm{n}=4$. Letters represent groups of significant difference based on Tukey test $(\alpha=0.05)$. 
Though many past studies have examined effects of temperature and N individually on HAB species, including cyanobacteria [11] [16] [36] [54], few studies have examined the interactive effects of $\mathrm{N}$ and temperature on the relative performance of $\mathrm{N}$ - and non- $\mathrm{N}$-fixing cyanoHABs [3]. Increases in $\mathrm{N}$ eutrophication should favor non- $\mathrm{N}$ over $\mathrm{N}$-fixing cyanoHABs, unless temperature has different effects on $\mathrm{N}_{2}$ fixation compared to metabolism of other forms of $\mathrm{N}$, etc., since $\mathrm{N}$ fixation is energetically more expensive. There have also been few studies that have examined how $\mathrm{N}$ and temperature interact with herbivory to affect algal growth, and few studies that have examined the effects of temperature and $\mathrm{N}$ on the food quality of algae (excluding toxin production) [55] [56] [57].

In the case of temperature alone, for all sampling dates, total algal community growth was highest at $30^{\circ} \mathrm{C}$, and similar between $20^{\circ} \mathrm{C}$ and $25^{\circ} \mathrm{C}$, and this same temperature response was observed for cyanobacteria, but not for green algae and diatoms. Notably, temperature responses were dependent on sampling date: e.g., little temperature response in green algae and diatoms on the early sampling dates (26 Aug., 13 Sept., 28 Sept.,), but a negative response to increasing temperature on the last sampling date (12 Oct.). Moreover, the phytoplankton community is adapted to the current temperature of lake and by October plankton would be cold-adapted relative to other sampling dates. Further, the response to temperature was sometimes modified by the presence/absence of herbivores: e.g., in green algae and diatoms, there was no temperature response with herbivores, but a positive response to temperature on 28 Sept., and a stronger negative response to high temperatures without herbivores on 12 Oct. Hence, any future increases in water temperature with global warming are likely to increase growth of cyanobacteria, relative to green algae and diatoms, in western Lake Erie, especially late in the summer and fall.

In the case of $\mathrm{N}$ alone, total algal community growth tended to increase with increasing $\mathrm{N}$ only at higher temperatures and on the early sampling dates (26 Aug., 13 Sept.), and tended to decrease with increasing $\mathrm{N}$ on the last sampling date (12 Oct.). For the major algal taxa examined (cyanobacteria, green algae, diatoms), positive $\mathrm{N}$ responses also tended to be observed primarily at the warmer temperatures and on the earlier sampling dates. Herbivores affected the response to $\mathrm{N}$ only in cyanobacteria (28 Sept.). Importantly, positive responses of algal growth to $\mathrm{N}$ generally were generally saturated by $50-150 \mu \mathrm{M}$ added $\mathrm{N}$, which is below maximum $\mathrm{N}$ levels observed in western Lake Erie (typically in spring and early summer), but are above the low $\mathrm{N}$ levels typically observed in the late summer and fall, when cyanobacterial blooms usually occur [22]. Further, M. aeruginosa isolate growth responded positively to added $\mathrm{N}$ at all growth temperatures examined and $\mathrm{A}$. flos-aquae did so only at $30^{\circ} \mathrm{C}$. As noted before, the positive response to $\mathrm{N}$ in M. aeruginosa was expected, but the positive response in A. flos-aquae was not, and indicates a shift from acquisition of $\mathrm{N}$ via $\mathrm{N}$ fixation exclusively at lower temperatures to acquisition of $\mathrm{N}$ as $\mathrm{NO}_{3}$ at higher temperatures, which may be driven by heat effects on $\mathrm{N}$ fixation or nitrogenase. The relative heat-sensitivity of nitrogenase has been noted previously [58]. It is also known that $\mathrm{N}$ fixation is typically inhibited by high levels of available inorganic $\mathrm{N}$, which can increase growth due to avoidance of the high metabolic cost of $\mathrm{N}$ fixation [59]; however, we did not observe increases in Anabaena growth with increasing $\mathrm{N}$ at $20^{\circ} \mathrm{C}$ or $25^{\circ} \mathrm{C}$, perhaps because use of additional $\mathrm{N}$ was constrained by sub-optimal temperature. Together, our results are consistent with previous studies that indicate that any additional $\mathrm{N}$ eutrophication of western Lake Erie is likely to fuel increases in cyanoHABs, and may interact with temperature to affect the relative success of $\mathrm{N}$-fixing and non- $\mathrm{N}$-fixing cyanobacteria (e.g., increased $\mathrm{N}$ without increased temperature could favor M. aeruginosa over A. flos-aquae, but the reverse might happen with increased $\mathrm{N}$ and temperature).

Effects of $\mathrm{N}$ and temperature on algae will likely have indirect interactive effects on algal herbivores, and these herbivore effects will then have cascading effects on other trophic levels and the entire aquatic ecosystem. For example, in this study, total algal growth tended to be higher in the absence of herbivores, and cyanobacterial growth tended to be higher in the presence of herbivores, though this depended sometimes on sampling date. These results are consistent with those of Wang [57], who showed in small-pond experiments that when zooplankton are removed, green algae and cyanobacteria remain in direct competition for nutrients, but when zooplankton were not removed, the zooplankton consumed the green algae, thus removing the cyanobacteria competitors. Given that cyanobacteria are typically not the preferred food of most algal herbivores [7], then any factor that increases growth of cyanobacteria relative to other major algal taxa, will impact zooplankton community structure [60]. Further, both $\mathrm{N}$ and temperature can be expected to influence the food quality of algae, and this will then impact the zooplankton community. For example, increases in $\mathrm{N}$ typically increase the protein content of algae [61], as observed in the present study, though only at higher temperatures. Also, higher-than-optimal 
temperatures usually decrease the content of NSC (due to increased respiration) and alter the composition of cell lipids (e.g., increasing fatty acid length and saturation) [62]. Though we observed little effect of temperature on NSC, we did observe increases in protein with increasing temperature. Notably, both $\mathrm{N}$ and temperature affect the toxicity of cyanobacteria, including M. aeruginosa [14] [23] [26] [27] [37] [63]-[66], and this will affect other trophic levels [60]. Finally, $\mathrm{N}$ and temperature will have direct effects on herbivores, which will impact herbivory. Hence, the interactive effects of increasing $\mathrm{N}$ and temperature will be multi-faceted.

\section{Conclusion}

CyanoHABs in freshwater ecosystems have been a major concern worldwide [1] [2] and are expanding geographically, threatening damage to some of the world's most-important water bodies. Our investigation showed temperature and $\mathrm{N}$ both affected algal growth, and there were temperature $\times \mathrm{N}$ interactions, which were sometimes affected by presence/absence of zooplankton. Protein content was increased by increasing temperature and $\mathrm{N}$ in Microcystis and Anabaena, but they had little consistent effect on NSC. In Anabaena, increases in N did not increase growth or protein at $20^{\circ} \mathrm{C}$ or $25^{\circ} \mathrm{C}$, but did increase both at $30^{\circ} \mathrm{C}$, indicating that $\mathrm{N}$ fixation is damaged at high temperatures and that high $\mathrm{NO}_{3}$ can overcome this damage. These results indicate that future global warming and continued eutrophication will increase cyanobacterial growth, as well influence algal herbivory and competition between $\mathrm{N}$-fixing and non- $\mathrm{N}$-fixing cyanobacteria. Thus, limiting anthropogenic $\mathrm{N}$ inputs into freshwater systems will be helpful in reducing algal blooms in the future as global climate warms.

\section{Acknowledgements}

We thank Mr. Peter Bichier for help with boat transport and sampling, and the Lake Erie Center for logistical support.

\section{References}

[1] Paerl, H.W. and Huisman, J. (2008) Blooms Like It Hot. Science, 320, 57-58. http://dx.doi.org/10.1126/science.1155398

[2] Paerl, H.W. and Paul, V.J. (2012) Climate Change: Links to Global Expansion of Harmful Cyanobacteria. Water Research, 46, 1349-1363. http://dx.doi.org/10.1016/j.watres.2011.08.002

[3] Havens, K.E., Fukushima, T., Xie, P., Iwakuma, T., James, R. T., Takamura, N., Hanazato, T. and Yamamoto, T. (2001) Nutrient Dynamics and the Eutrophication of Shallow Lakes Kasumigaura (Japan), Donghu (PR China), and Okeechobee (USA). Environmental Pollution, 111, 263-272. http://dx.doi.org/10.1016/S0269-7491(00)00074-9

[4] Qin, B., Zhu, G., Gao, G., Zhang, Y., Li, W., Paerl, H.W. and Carmichael, W.W. (2010) A Drinking Water Crisis in Lake Taihu, China: Linkage to Climatic Variability and Lake Management. Environmental Management, 45, 105-112. http://dx.doi.org/10.1007/s00267-009-9393-6

[5] Conley, D.J., Bonsdorff, E., Carstensen, J., Destouni, G., Gustafsson, B.G., Hansson, L.A., Rabalais, N.N, Voss, M. and Zillen, L. (2009) Tackling Hypoxia in the Baltic Sea: Is Engineering a Solution? Environmental Science and Technology, 43, 3407-3411. http://dx.doi.org/10.1021/es8027633

[6] Dodds, W.K., Bouska W.W., Eitzmann, J.L., Pilger, T.J., Pitts, K.L., Riley, A.J., Schloesser, J.T. and Thornbrugh, D.J. (2009) Eutrophication of U.S. Freshwaters: Analysis of Potential Economic Damages. Environmental Science and Technology, 43, 12-19. http://dx.doi.org/10.1021/es801217q

[7] Sarnelle, O., Gustafsson, S. and Hansson, L.A. (2009) Effects of Cyanobacteria on Fitness Components of the Herbivore Daphnia. Journal of Plankton Research, 32, 471-477. http://dx.doi.org/10.1093/plankt/fbp151

[8] Paerl, H.W. (2008) Nutrient and Other Environmental Controls of Harmful Cyanobacterial Blooms along the Freshwater-Marine Continuum. In: Hudnell, K.H., Ed., Cyanobacterial Harmful Algal Blooms: State of the Science Research Needs Series: Advances in Experimental Medicine and Biology, Vol. 619, Springer, New York, 217-237. http://dx.doi.org/10.1007/978-0-387-75865-7_10

[9] Gilbert, J.J. and Claska, M.E. (1998) The Effect of Temperature on the Response of Daphnia to Toxic Cyanobacteria. Freshwater Biology, 39, 221-232. http://dx.doi.org/10.1046/j.1365-2427.1998.00276.x

[10] Turner, T.J. and Tester, P.A. (1997) Toxic Marine Phytoplankton, Zooplankton Grazers, and Pelagic Food Webs. Limnology and Oceanography, 42, 1203-1214. http://dx.doi.org/10.4319/lo.1997.42.5_part_2.1203

[11] Jöhnk, K.D., Huisman, J., Sharples, J., Sommeijer, B., Visser, P.M. and Stroom, J.M. (2008) Summer Heat Waves Promote Blooms of Harmful Cyanobacteria. Global Change Biology, 14, 495-512. 
http://dx.doi.org/10.1111/j.1365-2486.2007.01510.x

[12] Wilhelm, S. and Adrian, R. (2008) Impact of Summer Warming on the Thermal Characteristics of a Polymictic Lake and Consequences for Oxygen, Nutrients and Phytoplankton. Freshwater Biology, 53, 226-237.

[13] Sommer, U. (1984) The Paradox of the Plankton: Fluctuations of Phosphorus Availability Maintain Diversity of Phytoplankton in Flow-through Cultures. Limnology and Oceanography, 29, 633-636. http://dx.doi.org/10.4319/lo.1984.29.3.0633

[14] Rapala, J., Sivonen, K., Lyra, C. and Niemela, S.I. (1997) Variation of Microcystins, Cyanobacterial Hepatotoxins, in Anabaena spp. as a Function of Growth Stimulation. Applied and Environmental Microbiology, 63, 2206-2212.

[15] Oliver, R.L. and Ganf, G.G. (2000) Freshwater Blooms. In: Whitton, B.A. and Potts, M., Eds., The Ecology of Cyanobacteria, Their Diversity in Time and Space, Kluwer Academic, Dordrecht, 149-194.

[16] Paerl, H.W., Fulton, R.S., Moisander, P.H. and Dyble, J. (2001) Harmful Freshwater Algal Blooms, with an Emphasis on Cyanobacteria. The Scientific World Journal, 1, 76-113. http://dx.doi.org/10.1100/tsw.2001.16

[17] Vitousek, P., Aber, J., Howarth, R., Likens, G., Matson, P., Schindler, D., Schlesinger, W. and Tilman, D. (1997) Human Alteration of the Global N Cycle: Causes and Consequences. Issues in Ecology, 1, 1-17.

[18] Carpenter, S.R., Caraco, N.F., Correll, D.L., Howarth, R.W., Sharpley, A.N. and Smith, V.H. (1998) Nonpoint Pollution of Surface Waters with Phosphorus and Nitrogen. Ecological Applications, 8, 559-568. http://dx.doi.org/10.1890/1051-0761(1998)008[0559:NPOSWW]2.0.CO;2

[19] Paerl, H.W. and Scott, J.T. (2010) Throwing Fuel on the Fire: Synergistic Effects of Excessive Nitrogen Inputs and Global Warming on Harmful Algal Blooms. Environmental Science and Technology, 44, 7756-7758. http://dx.doi.org/10.1021/es102665e

[20] Trimbee, A.M. and Prepas, E.E. (1987) Evaluation of Total Phosphorus as a Predictor of Relative Biomass of Blue-Green Algae with an Emphasis on Alberta Lakes. Canadian Journal of Fisheries and Aquatic Sciences, 44, 13371342. http://dx.doi.org/10.1139/f87-158

[21] Watson, S.B., McCauley, E. and Downing, J.A. (1997) Patterns in Phytoplankton Taxonomic Composition across Temperate Lakes of Differing Nutrient Status. Limnology and Oceanography, 42, 487-495. http://dx.doi.org/10.4319/lo.1997.42.3.0487

[22] Chaffin, J., Bridgeman, T. and Bade, D. (2013) Nitrogen Constrains the Growth of Late Summer Cyanobacterial Blooms in Lake Erie. Advances in Microbiology, 3, 16-26. http://dx.doi.org/10.4236/aim.2013.36A003

[23] Codd, G.A. and Poon, G.K. (1988) Cyanobacterial Toxins. In: Rogers, L.J. and Gallon, J.R., Eds., Biochemistry of the Algae and Cyanobacteria, Clarendon Press, Oxford, 283-296.

[24] Dokulil, M.T. and Teubner, K. (2000) Cyanobacterial Dominance in Lakes. Hydrobiologia, 438, 1-12. http://dx.doi.org/10.1023/A:1004155810302

[25] Chaffin, J.D., Bridgeman, T.B., Heckathorn, S.A. and Mishra, S. (2011) Assessment of Microcystis Growth Rate Potential and Nutrient Status across a Trophic Gradient in Western Lake Erie. Journal of Great Lakes Research, 37, 92100. http://dx.doi.org/10.1016/j.jglr.2010.11.016

[26] Orr, P.T. and Jones, G.J. (1998) Relationship between Microcystin Production and Cell Division Rates in NitrogenLimited Microcystis aeruginosa Cultures. Limnology and Oceanography, 43, 1604-1614. http://dx.doi.org/10.4319/lo.1998.43.7.1604

[27] Watanabe, M.F. and Oishi, S. (1985) Effects of Environmental Factors on Toxicity of a Cyanobacterium (Microcystis aeruginosa) under Culture Conditions. Applied and Environmental Microbiology, 49, 1342-1344.

[28] Vézie, C., Rapala, J., Vaitomaa, J., Seitsonen, J. and Sivonen, K. (2002) Effect of Nitrogen and Phosphorus on Growth of Toxic and Nontoxic Microcystis Strains and on Intracellular Microcystin Concentrations. Microbial Ecology, 43, 443-454. http://dx.doi.org/10.1007/s00248-001-0041-9

[29] Kay, R.A. and Barton, L.L. (1991) Microalgae as Food and Supplement. Critical Reviews in Food Science and Nutrition, 30, 555-573. http://dx.doi.org/10.1080/10408399109527556

[30] Hitchcock, G.L. (1980) Diel Variation in Chlorophyll $\alpha$, Carbohydrate and Protein Content of the Marine Diatom Skeletonema costatum. Marine Biology, 57, 271-278. http://dx.doi.org/10.1007/BF00387570

[31] IPCC (2007) A Report of Working Group I of the Intergovernmental Panel on Climate Change. Summary for Policymakers and Technical Summary.

[32] Canale, R.P. and Vogel, A.H. (1974) Effects of Temperature on Phytoplankton Growth. Journal of the Environmental Engineering Division, 100, 229-241.

[33] Paul, V.J. (2008) Global Warming and Cyanobacterial Harmful Algal Blooms. In: Hudnell, K.H., Ed., Cyanobacterial Harmful Algal Blooms: State of the Science Research Needs Series: Advances in Experimental Medicine and Biology, Vol. 619, Springer, New York, 239-257. http://dx.doi.org/10.1007/978-0-387-75865-7_11 
[34] Takamura, N., Iwakuma, T. and Yasuno, M. (1985) Photosynthesis and Primary Production of Microcystis aeruginosa Kütz in Lake Kasumigaura. Journal of Plankton Research, 7, 303-312. http://dx.doi.org/10.1093/plankt/7.3.303

[35] Robarts, R.D. and Zohary, T. (1987) Temperature Effects on Photosynthetic Capacity, Respiration, and Growth Rates of Bloom-Forming Cyanobacteria. New Zealand Journal of Marine and Freshwater Research, 21, 391-399. http://dx.doi.org/10.1080/00288330.1987.9516235

[36] Reynolds, C.S. (2006) Ecology of Phytoplankton. Cambridge University Press, Cambridge. http://dx.doi.org/10.1017/CBO9780511542145

[37] Sivonen, K. (1990) Effects of Light, Temperature, Nitrate, Orthophosphate, and Bacteria on Growth of and Hepatotoxin Production by Oscillatoria agardhii Strains. Applied and Environmental Microbiology, 56, 2658-2666.

[38] Renaud, S.M., Thinh, L.V., Lambrinidis, G. and Parry, D.L. (2002) Effect of Temperature on Growth, Chemical Composition and Fatty Acid Composition of Tropical Australian Microalgae Grown in Batch Cultures. Aquaculture, 211, 195-214. http://dx.doi.org/10.1016/S0044-8486(01)00875-4

[39] Bridgeman, T.B., Chaffin, J.D. and Filbrun, J.E. (2013) A Novel Method for Tracking Western Lake Erie Microcystis Blooms, 2002-2011. Journal of Great Lakes Research, 39, 83-89. http://dx.doi.org/10.1016/j.jglr.2012.11.004

[40] Stumpf, R.P., Wynne, T.T., Baker, D.B. and Fahnenstiel, G.L. (2012) Interannual Variability of Cyanobacterial Blooms in Lake Erie. PLOS ONE, 7, e42444. http://dx.doi.org/10.1371/journal.pone.0042444

[41] Guillard, R.R.L. and Lorenzen, C.J. (1972) Yellow-Green Algae with Chlorophyllidec. Journal of Phycology, 8, 10-14.

[42] Bista, D.R. (2012) Effect of Increased Temperature and Nitrogen on the Non-N-fixing vs. N-Fixing Cyanobacteria in Western Lake Erie: Implications for Competition and Climate Change. M.Sc. Disertation, University of Toledo, Toledo.

[43] Barnes, J.D., Balaguer, L., Manrique, E., Elvira, S. and Davison, A.W. (1992) A Reappraisal of the Use of DMSO for the Extraction and Determination of Chlorophylls $a$ and $b$ in Lichens and Higher Plants. Environmental and Experimental Botany, 32, 85-100. http://dx.doi.org/10.1016/0098-8472(92)90034-Y

[44] Seely, G.R., Ducan, M.J. and Vidaver, W.E. (1972) Preparative and Analytical Extraction of Pigments from Brown Algae with Dimethyl Sulfoxide. Marine Biology, 12, 184-188. http://dx.doi.org/10.1007/BF00350754

[45] Chaffin, J., Bridgeman, T., Heckathorn, S.A. and Krause, A. (2012) Role of Suspended Sediments and Mixing in Reducing Photoinhibition in the Bloom-Forming Cyanobacterium Microcystis. Journal of Water Resource and Protection, 4, 1029-1041. http://dx.doi.org/10.4236/jwarp.2012.412119

[46] Furuki, T., Maeda, S., Imajo, S., Hiroi, T., Amaya, T., Hirokawa, T., Ito, K. and Nozawa, H. (2003) Rapid and Selective Extraction of Phycocyanin from Spirulina platensis with Ultrasonic Cell Disruption. Journal of Applied Phycology, 15, 319-324. http://dx.doi.org/10.1023/A:1025118516888

[47] Sampath-Wiley, P. and Neefus, C.D. (2007) An Improved Method for Estimating R-Phycoerythrin and R-Phycocyanin Contents from Crude Aqueous Extracts of Porphyra (Bangiales, Rhodophyta). Journal of Applied Phycology, 19, 123129. http://dx.doi.org/10.1007/s10811-006-9118-7

[48] Dubois, M., Gilles, K.A., Hamilton, J.K., Rebers, P.A. and Smith, F. (1956) Colorimetric Method for Determination of Sugars and Related Substances. Analytical Chemistry, 28, 350-356. http://dx.doi.org/10.1021/ac60111a017

[49] Downing, T.G., Sember, C.S., Gehringer, M.M. and Leukes, W. (2005) Medium N:P Ratios and Specific Growth Rate Comodulate Microcystin and Protein Content in Microcystis aeruginosa PCC7806 and M. aeruginosa UV027. Microbial Ecology, 49, 468-473. http://dx.doi.org/10.1007/s00248-004-0054-2

[50] Long, B.M., Jones, G.J. and Orr, P.T. (2001) Cellular Microcystin Content in N-Limited Microcystis aeruginosa Can Be Predicted from Growth Rate. Applied and Environmental Microbiology, 67, 278-283. http://dx.doi.org/10.1128/AEM.67.1.278-283.2001

[51] Oh, H.M., Lee, S.J., Jang, M.H. and Yoon, B.D. (2000) Microcystin Production by Microcystis aeruginosa in a Phosphorus-Limited Chemostat. Applied and Environmental Microbiology, 66, 176-179. http://dx.doi.org/10.1128/AEM.66.1.176-179.2000

[52] Mishra, S., Heckathorn, S.A., Barua, D., Wang, D., Joshi, P., Hamilton III, E.W. and Frantz, J. (2008) Interactive Effects of Elevated $\mathrm{CO}_{2}$ and Ozone on Leaf Thermotolerance in Field Grown Glycine max. Journal of Integrative Plant Biology, 50, 1396-1405. http://dx.doi.org/10.1111/j.1744-7909.2008.00745.x

[53] Ghosh, S., Gepstein, S., Heikkila, J.J. and Dumbroff, E.B. (1988) Use of a Scanning Densitometer or an ELISA Reader for Measurement of Nanogram Amount of Protein in Crude Extracts from Biological Tissue. Analytical Biochemistry, 169, 227-233. http://dx.doi.org/10.1016/0003-2697(88)90278-3

[54] Tilman, D. (1982) Resource Competition and Community Structure. Princeton University Press, Princeton.

[55] Gilbert, J.J. and Claska, M.E. (1998) The Effect of Temperature on the Response of Daphnia to Toxic Cyanobacteria. Freshwater Biology, 39, 221-232. http://dx.doi.org/10.1046/j.1365-2427.1998.00276.x 
[56] Tillmanns, A.R., Wilson, A.E., Pick, F.R. and Sarnelle, O. (2008) Meta-Analysis of Cyanobacterial Effects on Zooplankton Population Growth Rate: Species-Specific Responses. Fundamental and Applied Limnology, 171, 285-295. http://dx.doi.org/10.1127/1863-9135/2008/0171-0285

[57] Wang, X., Qin, B., Gao, G. and Paerl, H.W. (2010) Nutrient Enrichment and Selective Predation by Zooplankton Promote Microcystis (Cyanobacteria) Bloom Formation. Journal of Plankton Research, 32, 457-470. http://dx.doi.org/10.1093/plankt/fbp143

[58] Compaoré, J. and Stal, L.J. (2010) Effect of Temperature on the Sensitivity of Nitrogenase to Oxygen in Two Heterocystous Cyanobacteria. Journal of Phycology, 46, 1172-1179. http://dx.doi.org/10.1111/j.1529-8817.2010.00899.x

[59] Marschner, H. (1995) Mineral Nutrition of Higher Plants. 2nd Edition, Academic Press, New York.

[60] Davis, T.W. and Gobler, C.J. (2011) Grazing by Mesozooplankton and Microzooplankton on Toxic and Non-Toxic Strains of Microcystis in the Transquaking River, a Tributary of Chesapeake Bay. Journal of Plankton Research, 33, 415-430. http://dx.doi.org/10.1093/plankt/fbq109

[61] Ananadhi Padmanabhan, M.R., Annam Renita, A. and Stanley, S.A. (2010) Studies on the Effect of Nitrogen Source and the Growth of Marine Microalgae Algae. In: Recent Advances in Space Technology Services and Climate Change (RSTSCC), Chennai, 13-15 November 2010, 350-352. http://dx.doi.org/10.1109/RSTSCC.2010.5712867

[62] Hochachka, P.W. and Somero, G.N. (2002) Biochemical Adaptation, Mechanism and Process in Hysiological Evolution. Oxford University Press, New York.

[63] Song, L., Sano, T., Li, R., Makoto, W.M., Liu, Y.D. and Kaya, K. (1998) Microcystin Production of Microcystis viridis (cyanobacteria) under Different Culture Conditions. Phycological Research, 42, 19-23. http://dx.doi.org/10.1046/j.1440-1835.1998.00120.x

[64] Jacoby, J.M., Collier, D.C., Welch, E.B., Hardy, F.J. and Crayton, M. (2000) Environmental Factors Associated with a Toxic Bloom Microcystis aeruginosa. Canadian Journal of Fisheries and Aquatic Sciences, 57, 231-240. http://dx.doi.org/10.1139/f99-234

[65] Sekadende, B.C., Lyimo, T.J. and Kurmayer, R. (2005) Microcystin Production by Cyanobacteria in the Mwanza Gulf (Lake Victoria, Tanzania). Hydrobiologia, 543, 299-304. http://dx.doi.org/10.1007/s10750-004-6949-6

[66] Wu, S.K., Xie, P., Liang, G.D., Wang, S.B. and Liang, X.M. (2006) Relationships between Microcystins and Environmental Parameters in 30 Subtropical Shallow Lakes along the Yangtze River, China. Freshwater Biology, 51, 23092319. http://dx.doi.org/10.1111/j.1365-2427.2006.01652.x 
Scientific Research Publishing (SCIRP) is one of the largest Open Access journal publishers. It is currently publishing more than 200 open access, online, peer-reviewed journals covering a wide range of academic disciplines. SCIRP serves the worldwide academic communities and contributes to the progress and application of science with its publication.

Other selected journals from SCIRP are listed as below. Submit your manuscript to us via either submit@scirp.org or Online Submission Portal.
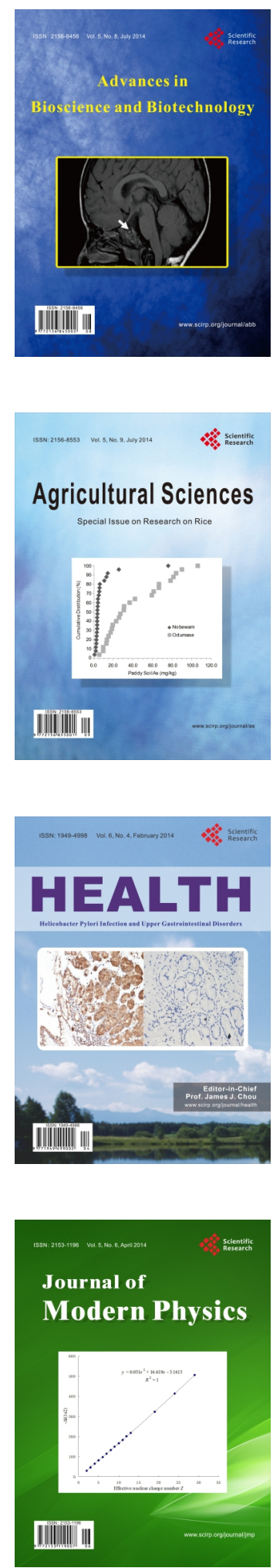
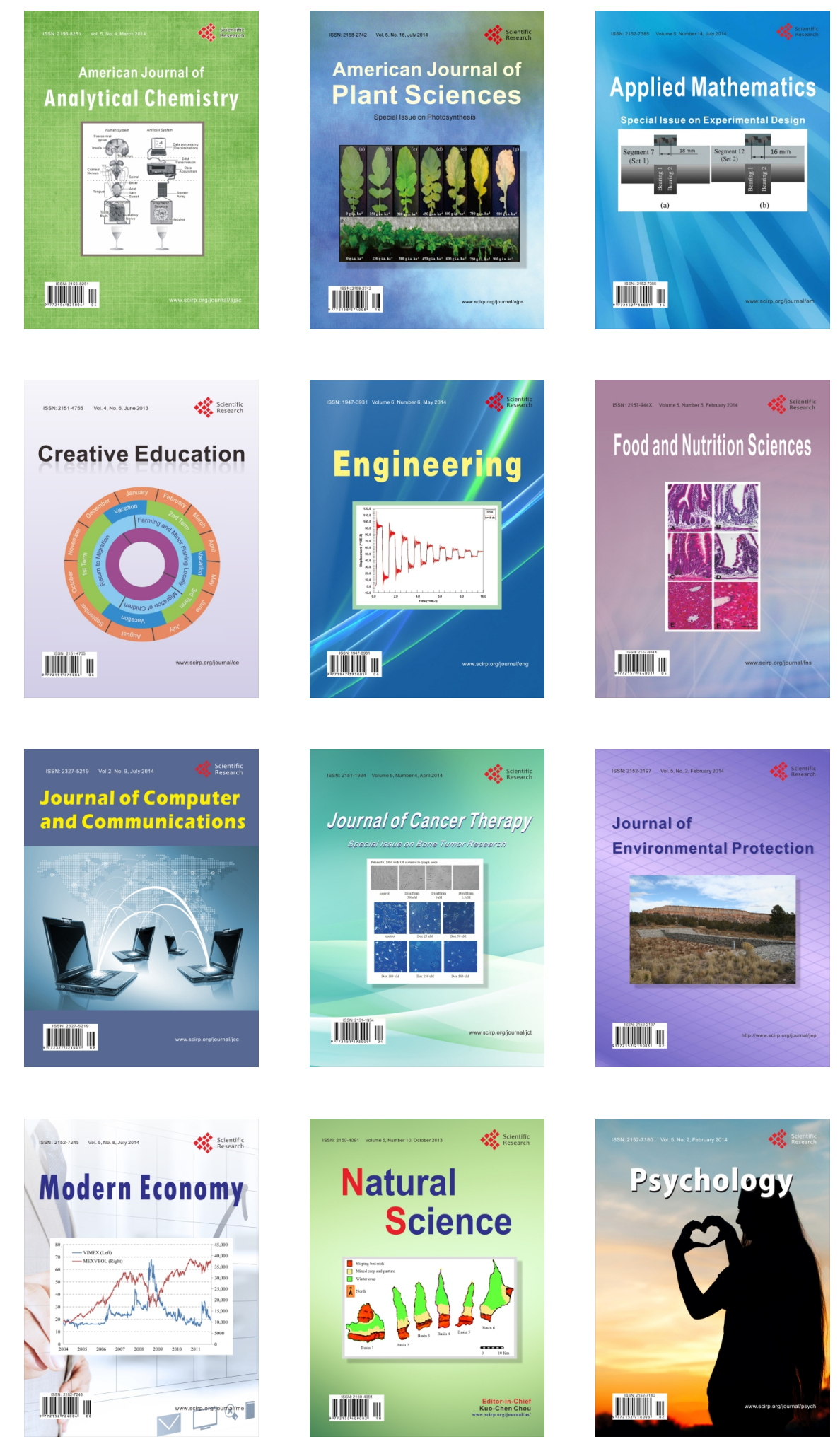